https://nv.nltu.edu.ua

https://doi.org/10.15421/40280805

Article received 14.10.2018 p.

Article accepted 25.10.2018 p.

$@ \square$ Correspondence author

V.P. Shlapak

удк 58.036.5:582.746.26(477.[4+7])

В. П. Шлапак', В. В. Мамчур ${ }^{1}$, О. М. Баюра ${ }^{1}$, Н. П. Шиак ${ }^{2}$ В. В. Шлапак ${ }^{3}$, О. Ю. Марно-Куца ${ }^{1}$

${ }^{l}$ Уманський національний університет садівництва, м. Умань, Украйна

${ }^{2}$ Національний природний парк "Кармелюкове Поділля", смт Чечельник, Украӥна

${ }^{3}$ Комунальне об'єднання "Київзеленбуд", м. Київ, Украӥна

\title{
ОСОБЛИВОСТІ КВІТУВАННЯ ТА ПЛОДОНОШЕННЯ AILANTHUS ALTISSIMA (MILL.) В УМОВАХ ПРАВОБЕРЕЖНОГО ЛІСОСТЕПУ І СТЕПУ УКРАЇНИ
}

\begin{abstract}
Досліджено тривалість і період квітування рослин (Ailanthus altissima Mill.) в умовах Правобережного Лісостепу і Степу України. Визначено, що тривалість і період квітування рослин інтродуцентів значною мірою залежить від кліматичних умов, в яких вони зростають. Досліджено, що рослини A. altissima належать до групи рослин із середньою тривалістю квітування. Оцінено рясність квітування рослин A. altissima в умовах Правобережного Лісостепу і Степу України. Визначено, що тривалість зав'язування та достигання плодів у рослин A. altissima настає в різні строки вегетаційного періоду залежно від середньодобової температури повітря та місця зростання цього виду. Досліджено, що дерева A. altissima у фазу плодоношення вступають у віці 10-15 років у південних областях Степу і в 15-18 років - в умовах Правобережного Лісостепу. Встановлено, що у досліджуваних рослин A. altissima впродовж вегетаційного періоду спостерігається стабільне квітування та плодоношення. Середній показник рясності квітування в умовах Правобережного Лісостепу був стабільним і оцінювався балом 4,5, а в Степу - 5 балів. Показник рясності плодоношення в Правобережному Лісостепу і Степу був стабільним і досить високим - 4,0 та 5,0 балів. Наведено результати дослідження середніх показників рясності квітування та плодоношення A. altissima, які зростають у Національному дендрологічному парку "Софіївка" НАН України, Уманському НУС, у зелених насадженнях. Умані та Уманського району, дендрологічному парку "Веселі Боковеньки" Кіровоградської обл. смт Чечельник Вінницької обл., в Одесі та Миколаєві.
\end{abstract}

Ключові слова: Ailanthus altissima (Mill.); квітування; плодоношення; рясність; декоративність.

Вступ. Тривалість і період квітування інтродукованих рослин значною мірою залежить від кліматичних умов, в яких вони зростають (Chmyr, Shlapak, Bektobekov, 1994). За тривалістю квітування рослини поділяють на групи: тривалоквітучі, із середньою тривалістю квітування та 3 короткою тривалістю квітування (Zауасhuk, 2004; Ziman, et al., 2004) А. altissima належить до групи рослин із середньою тривалістю квітування, оскільки період квітування представників досліджуваного виду триває місяць.

A. altissima - дводомне дерево. Квітки зібрані в жовтувато-зелені суцвіття - волоті, що формуються на кінці пагонів. Чоловічі суцвіття більші за розміром і сформовані більшою кількістю квітів, ніж жіночі (Engler, 1931; Heisey \& Heisey, 2003). Квітка має крихітні куполоподібні 5-лопатеві чашечки, віночок 3 п'ятьма чітко вираженими пелюстками та кільцевим 10-лопатевим гранулярним диском (Heninger \& White, 1974). Чолові- ча квітка має десять розширених функціонуючих каркасів, кожен з глобулярним родючим пиляком і гранулярний зелений диск. Плодолистики є рудиментарними або їх взагалі немає. Початок квітування у досліджуваних рослин в умовах Умані припадає на III декаду червня - I декаду липня. Триває квітування близько трьох тижнів.

Мета дослідження - вивчити й дослідити особливості квітування та плодоношення виду Ailanthus altissima (Mill.) в умовах Правобережного Лісостепу і Степу України.

Об'єкти та методика дослідження. Об'єктами дослідження є рослини A. altissima у Ботанічному саду Одеського національного університету ім. I. I. Мечникова, дендрологічному парку "Веселі Боковеньки" Кіровоградської обл., вуличних насадженнях смт. Чечельник Вінницької обл., на території Національного дендрологічного парку "Софіївка" НАН України, Уманського національного університету садівництва, вуличних

Інформація про авторів:

Шлапак Володимир Петрович, д-р с.-г. наук, професор, завідувач кафедри лісового господарства. Email: shlapakwp@gmail.com

Мамчур Валентина Василівна, викладач. Email: mamcurvalentina@gmail.com

Баюра Олександр Михайлович, канд. с.-г. наук, ст. викладач. Email: sasha-uman@ukr.net

Шпак Ніна Петрівна, наук. співробітник, відділ науки. Email: spaknina0@gmail.com

Шлапак Володимир Володимирович, головний спеціаліст. Email: shlapakwp@gmail.com

Марно-Куца Олена Юріївна, канд. с.-г. наук, ст. викладач. Email: leonora.marno@ukr.net

Цитування за Дсту: Шлапак В. П., Мамчур В. В., Баюра О. М. та ін. Особливості квітування та плодоношення Ailanthus Altissima (Mill.) в умовах правобережного лісостепу і степу України. Науковий вісник НЛтУ України. 2018, т. 28, № 8. С. $28-31$.

Citation APA: Shlapak, V. P., Mamchur, V. V., Bayura, A. M., et al. (2018). Some features of flowering and fruiting of Ailanthus Altissima Mill. in conditions of the right bank forest-steppe and steppe of Ukraine. Scientific Bulletin of UNFU, $28(8), 28-31$.

https://doi.org/10.15421/40280805 
насадженнях Умані, Куяльницького лиману, в садах та парках Черкаської, Кіровоградської, Одеської та Миколаївської областей. Обстежено 255 дерев A. altissima в умовах Правобережного Лісостепу і Степу України.

Рясність цвітіння оцінювали за 6 бальною шкалою О. А. Калініченка (Kalinichenko, 2000):

0 - цвітіння відсутне, частка покриття крони квітами з урахуванням закономірностей їх розміщення дорівнює 0 ;

1 - цвітіння дуже погане (0-20\%);

2 - цвітіння погане (20-40\%);

3 - цвітіння задовільне (40-60\%);

4 - цвітіння добре (60-80\%);

5 - цвітіння відмінне (80-100 \%).

Рясність плодоношення оцінювали за 6-бальною шкалою візуальної оцінки врожайності В. Г. Каппера (Kupper, 1930):

0 - неврожай - плоди відсутні.

1 - дуже поганий врожай, плоди утворились у невеликій кількості на рослинах, що ростуть поодиноко чи на узліссях, в середині деревостану чи групи - дуже рідко;

2 - слабкий врожай: спостерігається задовільне плодоношення на рослинах, що ростуть поодиноко, і слабке всередині деревостану чи групи;

3 - середній врожай: плодоношення дерев і чагарників, що зростають на узліссях та поодиноко, вище задовільного, а в середині деревостанів і груп - задовільне;

4 - добрий врожай: рясне плодоношення спостерігається на поодиноких деревах і чагарниках, а в групових насадженнях - задовільне;

5 - рясний врожай: рясне плодоношення спостерігається як на поодиноких рослинах, так і в середньовікових та зрілих деревостанах.

Результати дослідження. Під час досліджень оцінено рясність квітування рослин А. altissima за шкалою О. А. Калініченка (Kalinichenko, 2003). Результати проведених досліджень наведено в табл. 1 .

Найрясніше квітування A. altissima відзначено у вуличних насадженнях Одеси та Миколаєва (5,0 балів). Балом 4,5 оцінювали рослини, що ростуть у дендрологічному парку "Веселі Боковеньки" Кіровоградської обл., балом 4,5 - рослини, що ростуть в дендрологічному парку "Софіївка" Черкаської обл. Декоративність плодів зумовлюється їхніми розмірами, формою, кольором, терміном достигання та обпадання з рослин (Kottelova \& Grechko, 1969; Kokhno, 1991; Kokhno, 1986).

Табл. 1. Рясність квітування А. altissima у Правобережному Лісостепу і Степу України за 2014-2017 pp.

\begin{tabular}{|l|c|c|c|c|c|}
\hline \multirow{2}{*}{ Місце зростання } & \multicolumn{4}{|c|}{ Рясність квітування } & Середній \\
\cline { 2 - 5 } & 2014 & 2015 & 2016 & 2017 & бал \\
\hline $\begin{array}{l}\text { Дендрологічний парк } \\
\text { "Софіївка" }\end{array}$ & 4 & 4 & 5 & 4 & 4,3 \\
\hline $\begin{array}{l}\text { Дендрологічний парк } \\
\text { "Веселі Боковеньки" }\end{array}$ & 5 & 4 & 5 & 4 & 4,5 \\
\hline м. Одеса & 5 & 5 & 5 & 5 & 5,0 \\
\hline м. Миколаїв & 5 & 5 & 5 & 5 & 5,0 \\
\hline
\end{tabular}

Залежно від умов регіону зростання тривалість зав'язування та достигання плодів у рослин A. altissima настає в різні строки. В умовах Правобережного Лісостепу тривалість достигання плодів становить 87-90 діб, а в Степу - 80-85 діб. За нашими спостереженнями, фаза достигання плодів у Національному дендрологічному парку "Софіївка" розпочинається в наприкінці серпня і триває 35-40 діб. В Одеській і Миколаївській областях термін достигання плодів значно менший. Фаза достигання розпочинається наприкінці липня і становить 30-35 діб, що підтверджує різницю в тривалості формування насіння в різних регіонах. За нашими спостереженнями, дозрівання крилаток в умовах Умані починається наприкінці серпня.

Дозрівання крилаток значною мірою залежить від температури повітря та погодних умов і може тривати місяць і більше. На одному й тому самому дереві насіння дозріває неодночасно. Починають опадати плоди на початку липня (невиповнені та пошкодженні), а основна маса опадає на сніг взимку. Також треба зазначити, що частина крилаток залишається на дереві впродовж літа наступного року, а інколи й до кінця осені.

Дерева A. altissima у фазу плодоношення вступають у віці 10-15 років у південних областях Степу і в 1518 років - в умовах Правобережного Лісостепу. Водночас, паростеві дерева вегетативного походження не рідко розпочинають плодоносити у віці 3-5 років (рис. 1).
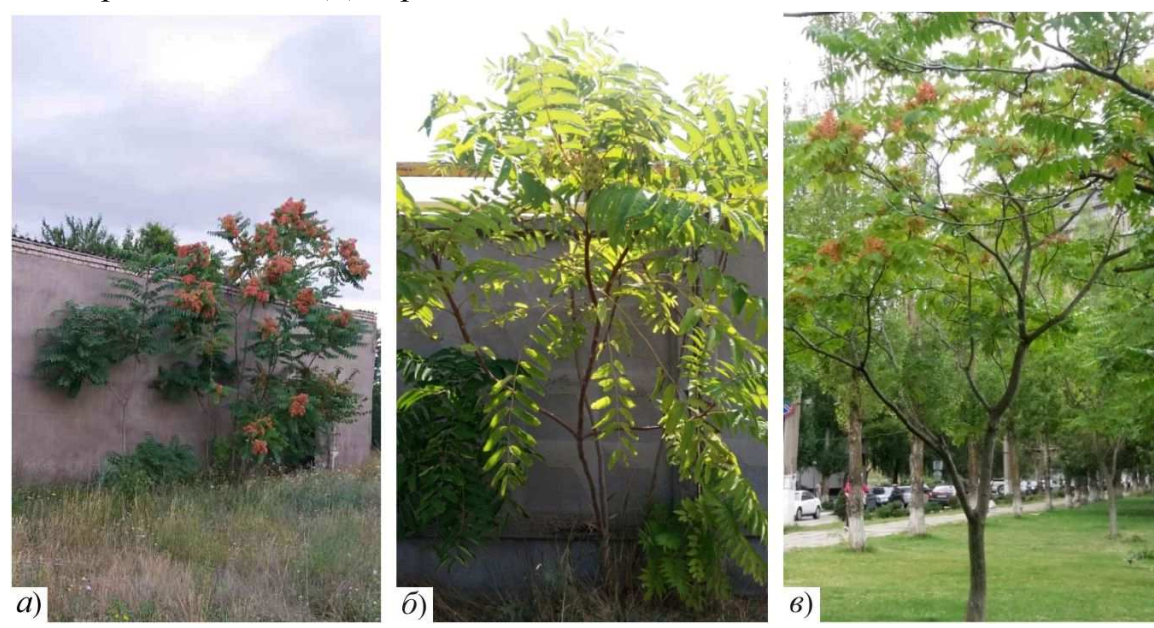

Рис. 1. Плодоношення дерев A. altissima вегетативного походження у віці 3-5 років в Одесі

Спостереження за рясністю плодоношення рослин $A$. altissima здійснювали впродовж чотирьох років, користуючись 6-бальною шкалою візуальної оцінки врожайності В. Г. Каппера (Kupper, 1930). Результати оцінювання рясності плодоношення наведено в табл. 2.
Для досліджуваного виду A. altissima характерна неоднакова рясність плодоношення. Найрясніше плодоношення характерне для рослин, що ростуть в Одеській і Миколаївській областях (див. табл. 2), де середній показник за чотири роки становив 5 балів. В умовах інтро- 
дукції Умані показник рясності плодоношення становив 4 бали.

Упродовж 2014-2017 pp. у досліджуваних видів спостерігалось стабільне плодоношення і показник рясності відповідно до шкали оцінювання був стабільним та досить високим (рис. 2).

Табл. 2. Рясність плодоношення А. altissima в умовах інтродукції в Правобережному Лісостепу і Степу України

\begin{tabular}{|c|c|c|c|c|c|}
\hline \multirow{2}{*}{ Місце зростання } & \multicolumn{4}{|c|}{ Рясність плодоношення } & \multirow{2}{*}{$\begin{array}{l}\text { Серед- } \\
\text { ній бал }\end{array}$} \\
\hline & 2014 & 2015 & 2016 & 2017 & \\
\hline \begin{tabular}{|l} 
Дендрологічний парк \\
"Софіївка" НАН України
\end{tabular} & 4 & 4 & 3 & 5 & 4,0 \\
\hline $\begin{array}{l}\text { Дендрологічний парк } \\
\text { "Веселі Боковеньки", } \\
\text { Кіровоградська обл. }\end{array}$ & 4 & 4 & 3 & 5 & 4,0 \\
\hline м. Миколаїв & 5 & 5 & 5 & 5 & 5,0 \\
\hline м. Одеса & 5 & 5 & 5 & 5 & 5,0 \\
\hline
\end{tabular}

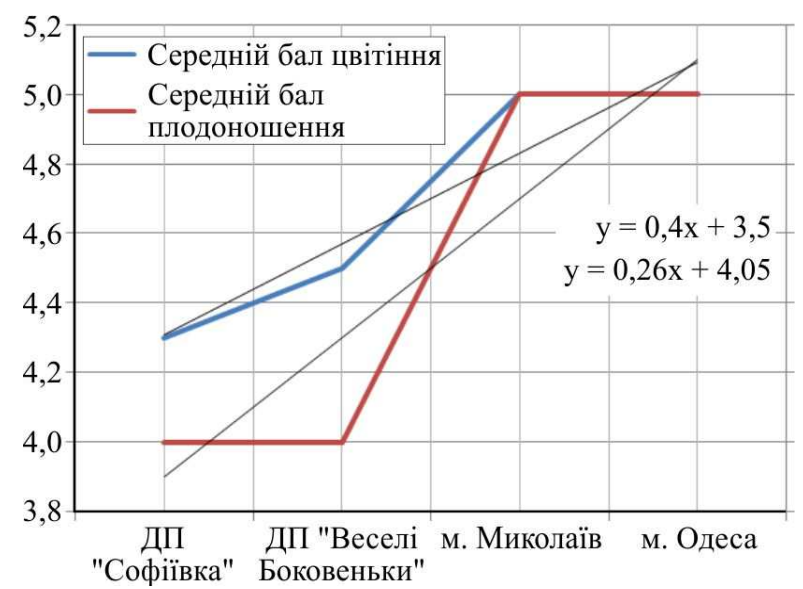

Рис. 2. Співвідношення рясності квітування та плодоношення A. altissima

У досліджуваних рослин A. altissima впродовж 2014-2017 pp. середній показник рясності квітування в умовах Правобережного Лісостепу є стабільним і оцінюється в 4,5 бала, а в Степу - 5 балів. Показник ряс- ності плодоношення в Правобережному Лісостепу і Степу був стабільним і досить високим - 4,0 та 5, 0 балів.

\section{Висновки:}

1. Упродовж 2014-2017 pр. у досліджуваних видів спостерігалось стабільне квітування та плодоношення і показник рясності відповідно до шкали оцінювання був стабільним і досить високим - 4,5 та 5 балів.

2. Дерева A. altissima насінного походження у фазу плодоношення вступають у віці $10-15$ років у південних областях і в 15-18 років - в умовах Правобережного Лісостепу. Водночас, дерева вегетативного походження розпочинають плодоносити у віці $3-5$ років.

\section{Перелік використаних джерел}

Chmyr, A. F., Shlapak, V. P., \& Bektobekov, V. P. (1994). Protection of the natural environment: Monographs. Kyiv: Libid. 240 p. [In Ukrainian].

Engler, A. (1931). Die Natrlichen Pflanzenfamilien, (Vol. 19a), (second ed.). Wilhelm Engelmann, Leipzig, 567 p.

Heisey, R. M., \& Heisey, T. K. (2003). Herbicidal effects under field conditions of Ailanthus altissima bark extract, which contains ailanthone. Plant Soil, 256, 85-99.

Heninger, R. L., \& White, D. P. (1974). Tree seedling growth at different soils temperatures. For. Sci. 20, 363-367.

Kalinichenko, O. A. (2000). Methodological guidelines for the study of discipline Dendrology. Kyiv: NNK NAU, 46 p.

Kalinichenko, O. A. (2003). Decorative dendrology. K. Higher School, $199 \mathrm{p}$.

Kokhno, N. A. (1986). Trees and shrubs cultivated in the USSR. K. Science. Opinion, $720 \mathrm{p}$.

Kokhno, N. A. (1991). Fruits and seeds of trees and shrubs cultivated in the Ukrainian SSR. K. Science. Opinion, $320 \mathrm{p}$.

Kottelova, N., \& Grechko, N. (1969). Evaluation of decorativeness. Floriculture, 10, 11-12.

Kupper, V. G. (1930). On the organization of annual systematic observations on the fruiting of tree species. Tr. on the forest expert case, L., 8, 103-139.

Zayachuk, V. Ya. (2004). Dendrology. Angiosperms. Lviv: Kamula, $408 \mathrm{p}$.

Ziman, S. M. (Ed.), et al. (2004). Illustrated reference book on the morphology of flowering plants. Uzhhorod: Medium, $156 \mathrm{p}$.

\section{В. П. Шлапак', В. В. Мамчур1, О. М. Баюра' , Н. П. Шиак ${ }^{2}$ В. В. Шлапак ${ }^{3}$, Е. Ю. Марно-Куца 1}

${ }^{l}$ Уманский национальный университет садоводства, г. Умань, Украина ${ }^{2}$ Национальный природный парк "Кармелюково Подолье", пгт Чечельник, Украина

${ }^{3}$ Коммунальное объединение "Киевзеленстрой", г. Киев, Украина

\section{ОСОБЕННОСТИ ЦВЕТЕНИЯ И ПЛОДОНОШЕНИЯ AILANTHUS ALTISSIMA (MILL.) В УСЛОВИЯХ ПРАВОБЕРЕЖНОЙ ЛЕСОСТЕПИ И СТЕПИ УКРАИНЫ}

Исследована продолжительность и период цветения растений A. altissima в условиях Правобережной Лесостепи и Степи Украины. Определено, что продолжительность и период цветения растений интродуцентов в значительной степени зависит от климатических условий, в которых они растут. Доказано, что растения A. altissima относятся к группе растений со средней продолжительностью цветения. Оценена обильность цветения растений A. altissima в условиях Правобережной Лесостепи и Степи Украины. Определено, что продолжительность завязывания и созревания плодов у растений A. altissima наступает в разные сроки вегетационного периода в зависимости от среднесуточной температуры воздуха и места произрастания данного вида. Доказано, что деревья A. altissima в фазу плодоношения вступают в возрасте 10-15 лет в южных областях Степи и в 15-18 лет - в условиях Правобережной Лесостепи. Установлено, что в исследуемых растений A. Altissima в течении вегетационного периода наблюдается стабильное цветение и плодоношение. Средний показатель обильности цветения в условиях Правобережной Лесостепи был стабильным и оценивался баллом 4,5, а в Степи - 5 баллов. Показатель обильности плодоношения в Правобережной Лесостепи и Степи был стабильным и достаточно высоким - 4,0 и 5, 0 баллов. Приведены результаты исследования средних показателей обильности цветения и плодоношения растений A. altissima, которые растут в Национальном дендрологический парке "Софиевка" НАН Украины, Уманском НУС, в зеленых насаждениях Умани и Уманского района, дендрологическом парке Веселые Боковеньки Кировоградской обл., пгт Чечельник Винницкой обл., в Одессе, Николаеве.

Ключевые слова: Ailanthus altissima (Mill.); цветение; плодоношение; обильность; декоративность. 


\section{SOME FEATURES OF FLOWERING AND FRUITING OF AILANTHUS ALTISSIMA MILL. IN CONDITIONS OF THE RIGHT BANK FOREST-STEPPE AND STEPPE OF UKRAINE}

The authors have investigated duration and period of flowering of plants Ailanthus altissima (Mill.) under the conditions of the right bank forest steppe and the Ukrainian steppe. We have determined that the duration and period of flowering of introduces plants to a large extent depends on the climatic conditions in which they grow. A. altissima plants are stated to belong to a group of plants with medium flowering duration. The abundance of flowering of $A$. altissima plants in the conditions of the right bank forest-steppe and steppe of Ukraine is estimated. The length of laying and reaching the fruits of $A$. altissima plants is determined to occur at different periods of the growing season, depending on the average daily temperature of the air and the place of growth of this species. We have also revealed that $A$. altissima trees enter the fruiting phase at the age of 10-15 years in the southern regions of the steppe and in the 15-18 years under the conditions of the right bank forest-steppe. A. altissima during the growing season has stable flowering and fruiting in the investigated plants. The average rate of flowering abundance in the conditions of the right bank forest-steppe was stable and was estimated at 4.5 , and in the steppe -5 points. The fertility abundance index in the right bank forest-steppe and the steppe was stable and quite high -4.0 and 5.0 points. The authors have presented the results of the study of the average parameters of the abundance of flowering and fruiting A. altissima, in green plantations growing in the National Dendrology Park "Sofiyivka" of the National Academy of Sciences of Ukraine, Uman NPC, Uman and Uman district, Dendrology Park "Veseli Bokovenki" Kirovograd region, urban area, Chethelnik Vinnitsa region, Odessa city, and Mykolayiv city. A. altissima flowering was defined to be the most noticeable in streets of Odessa and Mykolaiv (5.0 points). We evaluated plants growing in the Dendrology Park Vesely Bokoveniy, Kirovograd region as 4.5 points. Plants growing in the National Dendrology Park "Sofiyivka" of Cherkasy region were also evaluated as 4.5 points. The fruit harvesting phase in the National Dendrology Park "Sofiyivka" begins at the end of August and lasts for 3540 days. In Odessa and Mykolaiv regions, the term of fruit reaching is much lower. The achievement phase begins at the end of July and lasts for 30-35 days, which confirms the difference in the duration of seed formation in different regions. The decorative nature of the fruits is determined by their size, shape, color, and time of reaching and falling from the plants.

Keywords: Ailanthus altissima (Mill.); flowering; fruiting; abundance; decorative. 